\title{
The Influence of Exports on Technology Progress - Empirical Study Based on Multinational Panel Data
}

\author{
Qiang Jiang, Guangtong Wang* \\ School of Economics, Shanghai University, Shanghai, China \\ Email address: \\ Struggleqiang@163.com (Guangtong Wang) \\ ${ }^{*}$ Corresponding author
}

\section{To cite this article:}

Qiang Jiang, Guangtong Wang. The Influence of Exports on Technology Progress — Empirical Study Based on Multinational Panel Data. Journal of Finance and Accounting. Vol. 4, No. 2, 2016, pp. 64-70. doi: 10.11648/j.jfa.20160402.16

Received: March 29, 2016; Accepted: April 6, 2016; Published: April 14, 2016

\begin{abstract}
Using DEA method, the paper measures the 19 economies' total factor productivity in 1990-2012 including input of energy and mineral resources, and then empirically tests the influence of exports on technology progress based on Prebisch's "Core and Periphery Theory". Results indicate that exports of "peripheral" states hinder its technology progress, while "core" states' exports promote its technology progress. The heterogeneity further reveals value chain division fixed by intra-product trade dominated by multinational corporations, and developing countries have been locked in Production and assembly process, developed countries manage the joint production of international production factors relying on technological superiority. The unfair distribution of value chain cause the economy growth of "peripheral" countries under enormous pressure, and the consumption and output of a large number of low-level production factor reduce the potential of its long-run economic growth.
\end{abstract}

Keywords: Core and Periphery Theory, Exports, Technology Progress, Value Chain Division

\section{Introduction}

The scale and speed of technology progress have been advanced beyond our imagination after the arrival of information era, and international trade also presents a new feature of intra-product trade supported by industrial organization theory. The research of the relationship between exports and economic growth based on the opening view and integration of world economy has been chased by large numbers of scholars. Experiencing from inter-industry trade to intra-industry trade ,and then to intra-product trade, Exports bring every economy into the global production system gradually and Effectively realize the global resources rational allocation. However, under this background, divergence appears among various countries' economic growth performance: Carrying out export-oriented economic development strategy similarly, the performance of Japan and the "Asian tigers" fully affirmed the positive role of exports on economic growth; but most countries of southeast Asia get into "middle-income trap" with a rising share of exports to GDP. Especially in nearly 20 years, these countries and regions' performance between exports and economic growth more and more deviates from the experience of Japan and "Asian tigers". Tracing back to the early 1970s, development economist, Prebisch, pointed out the "Core and Periphery Theory" and argued that technological progress is the cause of this differentiation. Technology advanced countries became the centre of the world's economic system, while technology backward countries turned to be the edge of the system. Nowadays, multinational corporations in the developed countries organize high-end production factors flowing on every corner of the world and realize joint production with low-end production factors from developing countries, which prompts international trade evolving from Intra-industry trade to intra-product trade. A large number of intermediate goods export and misty property-rights attributes behind added value make the relationship between exports and economic growth turn to be more complex. Justly based on short-run demand to measure the relationship between export and economic growth haven't already adapted to the reality that increasingly division of value chain, so turning to the research that the influence of exports on technology progress will contribute to 
improve evaluation system of export. Measuring the role of export accurately which has important theoretical and practical significance.

Does the expansion of export promote technology progress? Does the Heterogeneity that the relationship between exports and technology progress among "core" states and "peripheral" states exist? This paper attempts to examine these two major problems. Arrangement of this paper is as follows: The second part is literature review; The third part is the model set and data declaration; The fourth part is the measurement of total factor productivity; The fifth part is the empirical process and results; The last part is conclusion and enlightenment.

\section{Literature Review}

Technological progress is the driving force of economic growth [15], the relationship between trade and technological progress has always been the hot spot of the academic research [2]. The research of influence of exports on technology progress would be spreaded the discussion mainly from four aspects: the human capital promotion effect, learning by exporting, stimulating research and development investment, scale economy. Grossman \& Helpman [9] analyzed that exports can stimulate one country's human capital accumulation and promotion from the aspect that exports will enhance the demand of high-skill labors, and then it also has a positive effect for human capital promotion in no-export department when the labors trained by exports department flow to no-export department. Learning by exporting is another important path that exports can promote technological progress. Through the research on data from 1991 to 1996 Spanish micro manufacturing enterprise, Delgada et al. [5] showed that there is "Learning By Exporting" effect in young micro enterprises. Rodrigue [14] researched the process of exports involving multinational joint production, micro company will get more learning opportunities on account of high-standard seted by developed countries during the process of multinational joint production. Facing with the external severe market competition, the micro export enterprises have to add input of R\&D in order to respond this competition. Dilling-Hanse \& Smith [6] analyzed the relationship among exports, R\&D investment and the company productivity using data of the Danish services industry. Results show that export enterprises have more motivation of $R \& D$ investment, in order to enhance competition, comparing with no-export enterprises. New economic growth theory represented by Krugman [11] pointed out that exports can achieve scale economy, improve the efficiency of resource allocation, realize the enhancement of TFP. Using Singapore 1974-1995 panel data of 10 major industries, Thangavelu \& Owyong [17] conducted empirical analysis to the infuence of exports on production efficiency of Singapore manufacturing industry, results show that exports enhanced the TFP of related industries through scale economy. Although there are four major paths of exports enhancing the technology progress, the process will be influenced by one country's market environment, technology absorption capacity, technological gap and other factors of host countries. Taking the influence of exports on human capitcal as an example, Does exports enhance one countries' human capital? This issue cause controversy of some scholars! Acemoglu [1] considered exports can enhance one countries' human capital through stimulating the demand of high-skill labors, but Long et al. [13] think that exports cann't enhance the human capital for less-developed countries on account of the demand of hige-skill labor is less which lead to the relative wage of high-skill labors is lower comparing with developed countries. With global economy integration evolving towards to deep direction, world economy presents a series of new characteristics nowadays: Production factors realize optimal allocation in every corner of the world through international investment dominated by multinational companies; International production segmentation lead intra-product trade taking place of intra-industry trade gradually, and intermediate goods have become the mainstream of the exports; The global joint production driving by multinational companies' foreign direct investment, which urge merchandise exports structure of developing countries converging to the level of developed countries; By virtue of controling the core production factors, developed countries make use of technology advantage to implement new economic plunder to less-developed countries. That the emergence of a series of new features in world economy complicates the influence of exports on one country's technology progress. For example, according to "Learning By Exporting" theory, the opportunity of learning by exporting exists on the high-end position of value chain. But the distribution of value chain among different countries is inequality. Technology leading economies occupy the upstream of value chain, which have more opportunities of learning by exporting; while developing countries laging in technology locate in the downstream of value chain, so have few opportunities of learning by exporting. The influence of exports on countries' technology progress will present great heterogeneity by reason of different countries in different links of value chain when the trade enter into intra-production trade period. Most existing literatures always aims at single country study of relationship between exports and technology progress. These research can clarify a specific country's role of exports on technology progress, but under the new characteristics of world economic integration, analyzing this heterogeneity fully that the influence of exports on disparate countries' technology progress cann't be realized. In view of this, this article will try to expand the research from the following several aspects: Firstly, Based on the resources endowment theory of Stiglitz [16], we measure several major countries' total factor productivity including input of nature resources; Secondly, comparing the subsample, we empirically test this heterogeneity that the influence of exports on technology progress between "core" states and "periphery" states. Finally, we analyze the reason why this heterogeneity exists, and provide empirical interpretation for recognizing the essence of exports in the stage of intra-production trade. 


\section{Model Setting and Data Sourcing}

\subsection{Model Setting}

Excepting exports, the major explanatory variable. We take imports, FDI, R\&D spending and the degree of financial market development as important control variables adding into the model. Being similarity with exports, imports and FDI could enhance countries' technology progress through the path of technology spillover and diffusion. Imports and FDI also prompt the micro enterprises to add $\mathrm{R} \& \mathrm{D}$ input in order to face the competition from multinational corporations. This process will enhance the TFP of micro enterprises. R\&D spending determines the strength of research and development, which can prompt one state's technology progress by supporting R\&D activities. The risks beared by enterprises when conducting technology innovation project need support from financial market. As is well-known, Innovation has the characteristic of high risk. Way of financing that bank loans as the major enterprises' capital source need enterprises take risks, while way of financing from stock marker and venture investment will lower the risks beared by enterprises, and which will raise the innovation enthusiasm. We add a dummy variable of state type in order to distinguish the heterogeneity that influence of exports on technology progress. Econometric model setting as follows:

$$
\begin{aligned}
T F P_{i t}= & C+\alpha_{1} E x_{i t}+\alpha_{2} \operatorname{Im}_{i t}+\alpha_{3} F D I_{i t}+\alpha_{4} R \& D_{i t} \\
& +\alpha_{5} C M_{i t}+\alpha_{6} D V_{i t}+u_{i t}+\varepsilon_{i t}
\end{aligned}
$$

TFP denotes a state's total factor productivity which measured by DEA method. Ex denotes a state's exports, Im denotes a state's imports, FDI denotes a state's foreign direct investment, $R \& D$ denotes a state's input of research and development, $C M$ denotes a state's level of financial market development. $D V$ is the dummy variable of state type. According to the classification of world bank, per capita GDP over $\$ 12276$ is developed countries, and the value of DV is 1 , if not is 0 .

\subsection{Variables Explanation}

We use the share of exports on GDP as measurable indicator of $E x$, the major explanatory variable; the share of imports on GDP as measurable indicator of $\mathrm{Im}$; the share of foreign direct investment on GDP as measurable indicator of FDI ; the share of research and development on GDP as measurable indicator of $R \& D$; the share of total market value of stock market on GDP as measurable indicator of $C M$.

\subsection{Sample Selection}

Global economic integration gradually incorporates opening economies into the world production system. According to the prebisch's point of view, the two camps of export-oriented economies mainly include "core and periphery" states, which scatters at Americas, Asia and Europe. Considering the availability of data, we select 1990-2012, eight "core" countries and eleven "peripheral" countries as sample ${ }^{1}$.

\subsection{Data Sourcing}

The total factor productivity of sample countries will be calculated by the method of DEA, essential data mainly roots from the International Labor Organization database, the U.S. Geological Survey database, the World Bank database, the United Nations database, yearbook of World Energy Statistics, the Mineral Resources Statistics Yearbook.

\section{The Calculation of Total Factor Productivity}

\subsection{Calculating Methods}

SFA, DEA and solow residual value are common methods to calculate total factor productivity, difference in method selection will lead to difference measuring results. Taking China For Example, Krugman, famous economist, calculated the TFP of China in the 1980 s, results show that there is no enhancement, even there is decline in some years [12], the same conclusion is as Bhagwati [3]. However, some scholars also have conclusion contrary to Krugman's. Such as Chow [4]. Determinants of different measuring results are the measure method and production factor selection.

On the conference paper of Asian development bank, Felipe [7] pointed out that the method of measuring the total factor productivity directly determines the conclusion of the regional economy growth quality. Among the several methods of calculating TFP, solow residual value need set the pattern of function, which has advantages when the numbers of input factor are two, labors and capital. As to production function of more than two elements input, DEA method can calculate the total factor productivity, needlessly considering the specific production function and output elasticity of factors. Based on this, we adopt DEA, data envelopment analysis, to measure sample states' total factor productivity. Due to the heterogeneity of resources endowment among different states, we introduce the nature resource as the third input factor on the basis of two fundamental factors, labor and capital.

\subsection{Specific Data Processing and Source}

Labor data of sample states come from the International Labor Organization database. GDP, converted to the based year 1990 by GDP price index, comes from the World Bank database, and GDP price index also comes from the World Bank database. Nature resource includes energy and mineral resources. We calculate the value of Coal, oil, natural gas three kinds of energy and iron, copper, aluminum, gold, silver, five kinds of mineral resources. The following paragraphs are the detailed introduction of the calculating process of nature resource value and capital stock.

1 Sample countries including: the United States, Canada, Italy, Britain, France, Germany, Australia, Finland, eight typical "core" countries; Mexico, Argentina, Brazil, China, Russia, India, Indonesia, Philippines, Turkey, Chile, South Africa, eleven typical "peripheral" countries. 
Sample states' output of coal, oil, natural gas and its price come from the World Energy Statistical Yearbook, which provides coal prices of the north-western Europe market and central areas of the United States. On the whole, the coal price of America slightly lower than the European market'. Due to the decline in commodity transportation cost and the restriction of international futures market, coal price distinction of the two regions is not large as our imagination, so we take the arithmetic average of the two region prices as the world's coal prices. The World Energy Statistics Yearbook provides unit price with the barrel of crude oil, but sample countries' output data is in tons. In order to realize unity of Unit of measurement, we adopt the standard that one ton of oil equals about 8 barrels of crude oil which comes from wikipedia. The World Energy Statistical Yearbook supplies oil prices of four regions, Dubai, Brent, Nigeria Forcados, West Texas. We take the arithmetic average of the four regions' oil prices as the world oil price. The World Energy Statistical Yearbook supplies some countries' natural gas prices, British HeLun NBP price, American Henry HUB price, Canada YBD price among those prices are formed by the market competition of supply and demand, to some degree, which are less affected by the geopolitical and international relations. We take the arithmetic average of these three states' prices as the world natural gas price.

Sample states' output of iron ore, alumina, gold, silver, copper comes from the Mineral Resources Statistics Yearbook of United States Geological Survey (USGS). Monetary value of iron ore adopt the price announced by U.S. mining bureau, but the grade of iron ore exists large distinction among different states. Some regions' grade of iron ore are higher, mainly in Australia, Brazil, Russia, Switzerland, the four countries. Other sample states' grade of iron ore are almost equal to USA, about thirty percent ${ }^{2}$. So we calculate the sample states' value of iron ore taking the grade of iron ore as weights on the basis of iron ore price of the United States. Monetary value of copper ore comes from the U.S. statistical bureau website, which supplies the gross tonnage and total value of copper ore exported to other states form the U.S.. So we calculate the unit value of copper ore based on the gross tonnage and total value ${ }^{3}$. As to the unit value of aluminum, we calculate it based on the gross aluminium output and total value provided by the U.S. geological survey. We adopt the gold and silver price of U.S. as the world gold and silver price. The unit value of gold and silver will be calculated as the method of copper. The data, gross exploitation quantity and total value of gold and silver, comes from United States Geological Survey (USGS).

2 According to the mineral commodities Summary of the U.S. geological survey (USGS) 2005, Australian iron ore grade is $57 \%$ and $60 \%$ in Brazil, $46 \%$ in Russia, $50 \%$ in Sweden.

3 Due to the high price of unit copper ore, so the transportation cost relative to the price of unit copper ore is low, which could lead the price of copper ore converge to common world price. According to our calculation of host countries' copper ore price exported by the United States. The prices among sample countries are floating within $4 \%$. Because of the higher unit value of aluminium, gold, silver, the floating rang will be smaller than copper'
We adopt the perpetual inventory method to calculate the capital stock of sample countries [8]. Fixed capital formation is the measurable indicator of investment flow which comes from World Bank database. Capital depreciation rate adopts 5\%, the research result of Hall and Jones [10]. Fixed capital formation would be translated to the price standard of 1990 by price index of investment in fixed assets. The data of price index of investment in fixed assets comes from the Penn World Table. The estimation of capital stock in initial year adopts the method of the ratio of capital to output. As to sample states' ratio of capital to output, KLEMS database of European GGDC put out some datas. Missing datas would be estimated by the existing data. Generally speaking, higher level economic development always accompanies with higher ratio of capital to output. But when the economic development reach to a fixed level as some develeped states, the ratia of capital to output will keep stability at the same level. As described in the classical economic growth model, when the macro economy reach to steady state, the new capital is mainly to compensate for the capital depreciation. The ratio of capital to output will never change without technology progress. We calculate the missing sample countries' data rely on the data supplied by KLEMS database according to the level of sample countries' economic development. China's ratio of capital to output is the reference standard of other BRICK countries and developing countries, while German's ratio of capital to output is the reference standard of developed countries. Sample countries includes the United States, Britain, France, Germany, Canada, Australia, Italy, Finland, China, India, Indonesia, the Philippines, Russia, Brazil, South Africa, Chile, Mexico, Argentina, Turkey, 19 countries.

\subsection{Specific Calculating Result}

The following table gives sample countries' calculation results of TFP including energy and mineral resources input. Due to space limitations, data every four years and last year are given as follows:

Table 1. Sample countries' TFP.

\begin{tabular}{llllllll}
\hline \multicolumn{1}{r}{ year } & $\mathbf{1 9 9 0}$ & $\mathbf{1 9 9 5}$ & $\mathbf{2 0 0 0}$ & $\mathbf{2 0 0 5}$ & $\mathbf{2 0 1 0}$ & $\mathbf{2 0 1 2}$ \\
\hline country & & & & & & \\
the United & 1.0000 & 1.0952 & 1.2032 & 1.2630 & 1.2648 & 1.2992 \\
States & & & & & & \\
Britain & 1.0000 & 1.1090 & 1.2242 & 1.3567 & 1.3190 & 1.3296 \\
France & 1.0000 & 1.0771 & 1.2292 & 1.2650 & 1.2019 & 1.2055 \\
Germany & 1.0000 & 1.0600 & 1.1463 & 1.1682 & 1.2161 & 1.2689 \\
Canada & 1.0000 & 1.0558 & 1.1312 & 1.1481 & 1.0922 & 1.1009 \\
Australia & 1.0000 & 0.9991 & 1.0168 & 1.0105 & 0.9775 & 0.9755 \\
Italy & 1.0000 & 1.0725 & 1.1461 & 1.1459 & 1.0856 & 1.0615 \\
Finland & 1.0000 & 1.0242 & 1.2565 & 1.3992 & 1.3602 & 1.3489 \\
China & 1.0000 & 0.7900 & 0.6550 & 0.5747 & 0.5169 & 0.4818 \\
India & 1.0000 & 0.7316 & 0.5869 & 0.4540 & 0.3738 & 0.3484 \\
Russia & 1.0000 & 0.6102 & 0.5409 & 0.5190 & 0.4348 & 0.3867 \\
Brazil & 1.0000 & 0.7742 & 0.6048 & 0.5684 & 0.5582 & 0.5515 \\
South Africa & 1.0000 & 0.8185 & 0.7736 & 0.7296 & 0.6548 & 0.6463 \\
Indonesia & 1.0000 & 0.8022 & 0.5930 & 0.6085 & 0.6307 & 0.6351 \\
Philippines & 1.0000 & 0.6005 & 0.4572 & 0.4232 & 0.4560 & 0.4654 \\
Chile & 1.0000 & 0.7638 & 0.5867 & 0.5349 & 0.4695 & 0.4588 \\
Mexico & 1.0000 & 0.5895 & 0.4921 & 0.3784 & 0.3103 & 0.3041 \\
Argentina & 1.0000 & 0.8132 & 0.5093 & 0.4664 & 0.4576 & 0.4508 \\
Turkey & 1.0000 & 0.9975 & 1.0113 & 1.1566 & 0.9974 & 0.9921 \\
\hline
\end{tabular}




\section{Empirical Test}

Empirical test based on the 1990-2012 panel data of 19 sample countries. Table 2 reports some statistical information between dependent variable and explanatory variables.

Table 2. Statistical information of variables.

\begin{tabular}{|c|c|c|c|c|c|c|c|}
\hline Variables & $\boldsymbol{Y}$ & $E x$ & Im & FDI & $R \& D$ & $C M$ & $D M$ \\
\hline$Y$ & 1 & & & & & & \\
\hline$E x$ & 0.0187 & 1 & & & & & \\
\hline Im & -0.0157 & $0.9243 *$ & 1 & & & & \\
\hline$F D I$ & 0.0331 & $0.1841 *$ & $0.1414 *$ & 1 & & & \\
\hline$R \& D$ & $0.3460 *$ & -0.0896 & -0.09955 & -0.0202 & 1 & & \\
\hline$C M$ & -0.0027 & $0.1287 *$ & $0.1453^{*}$ & $0.2052 *$ & $0.3011^{*}$ & 1 & \\
\hline$D M$ & $0.4008^{*}$ & 0.0673 & 0.0612 & -0.0783 & $0.8421^{*}$ & $0.2176^{*}$ & 1 \\
\hline observed number & 437 & 437 & 437 & 437 & 437 & 437 & 437 \\
\hline mean & 0.5836 & 25.30 & 25.07 & 0.0234 & 1.094 & 67.375 & 0.375 \\
\hline standard deviation & 0.2148 & 9.7291 & 9.425 & 0.0203 & 0.8303 & 49.388 & 0.485 \\
\hline minimum & 0.3041 & 6.706 & 8.874 & 0.0027 & 0.02 & 5.6343 & 0 \\
\hline maximum & 1.3992 & 52.968 & 59.293 & 0.1200 & 2.9191 & 278.392 & 1 \\
\hline
\end{tabular}

Note: ***,**, indicate $1 \%, 5 \%$ and $10 \%$ significance level respectively

Statistical analysis of whole data shows that there is no significant influence of exports on technological progress. Variance inflation factor is within the range of $[1.11,7.06]$, from which we consider that it exists partial multicollinearity to some degree. In order to test the view of this paper robustly, More specification of econometric analysis is needed to act on panel data. Table 3 shows the empirical results as follows:

Table 3. The empirical results of influence of exports on technology progress.

\begin{tabular}{lllll}
\hline Model & $\begin{array}{l}\text { mixed } \\
\text { OLS }\end{array}$ & 2SLS & LIML & GMM \\
\hline \multirow{2}{*}{$E x$} & 0.024 & 0.0129 & 0.0129 & 0.0129 \\
& $(1.19)$ & $(0.60)$ & $(0.60)$ & $(0.80)$ \\
Im & -0.028 & -0.0093 & -0.0093 & -0.0093 \\
& $(-1.33)$ & $(-0.43)$ & $(-0.43)$ & $(-0.48)$ \\
$F D I$ & 5.792 & $7.8476^{* * *}$ & $7.8476^{* * *}$ & $7.848^{*}$ \\
& $(1.54)$ & $(2.57)$ & $(2.57)$ & $(1.81)$ \\
$R \& D$ & 0.819 & 0.1102 & 0.1102 & 0.110 \\
& $(0.46)$ & $(0.76)$ & $(0.76)$ & $(1.01)$ \\
$C M$ & $-0.0034^{* *}$ & $-0.005^{* * *}$ & $-0.005^{* * *}$ & -0.005 \\
& $(-2.08)$ & $(-3.67)$ & $(-3.67)$ & $(-1.55)$ \\
$D M$ & $1.176^{* * *}$ & $1.158^{* * *}$ & $1.158^{* * *}$ & $1.158^{* * *}$ \\
& $(3.92)$ & $(4.81)$ & $(4.81)$ & $(10.62)$ \\
$C$ & -0.432 & $-0.592^{* * *}$ & $-0.592^{* * *}$ & $-0.592^{* * *}$ \\
Hausman & $(-1.61)$ & $(-2.66)$ & $(-2.66)$ & $(-2.81)$ \\
endogenous & & & & \\
test chi2 & & $60.05^{* * *}$ & & \\
\hline
\end{tabular}

Note: the number of ( ) is the $t$ statistical magnitude of regression coefficient, $* * *, * *, *$ indicate $1 \%, 5 \%$ and $10 \%$ significance level respectively.

Empirical analysis of OLS shows that there is no significant linear correlation betweent exports and technology progress. Hausman test indicates that model exists endogeneity problem. We select export lagging behind a period as instrumental variable. After exogeneity test of instrumental variable, The empirical results of two-stage least squares and GMM still cann't support the linear correlation between export and technological progress. Maximum likelihood regression of weak instrumental variable still has no substantial changes. But the dummy variable of state types is highly significant, which reflect a reality that there exists a heterogeneity that the influence of exports on technology progress among different states. In order to show the relationship between exports and technology progress more intuitively, we present the scatter diagram of two kinds of states between export and TFP, and indicate its fitted regression line as follows. Left figure is the scatterplot of developing countries, while right figure is the scatterplot of developed countries.
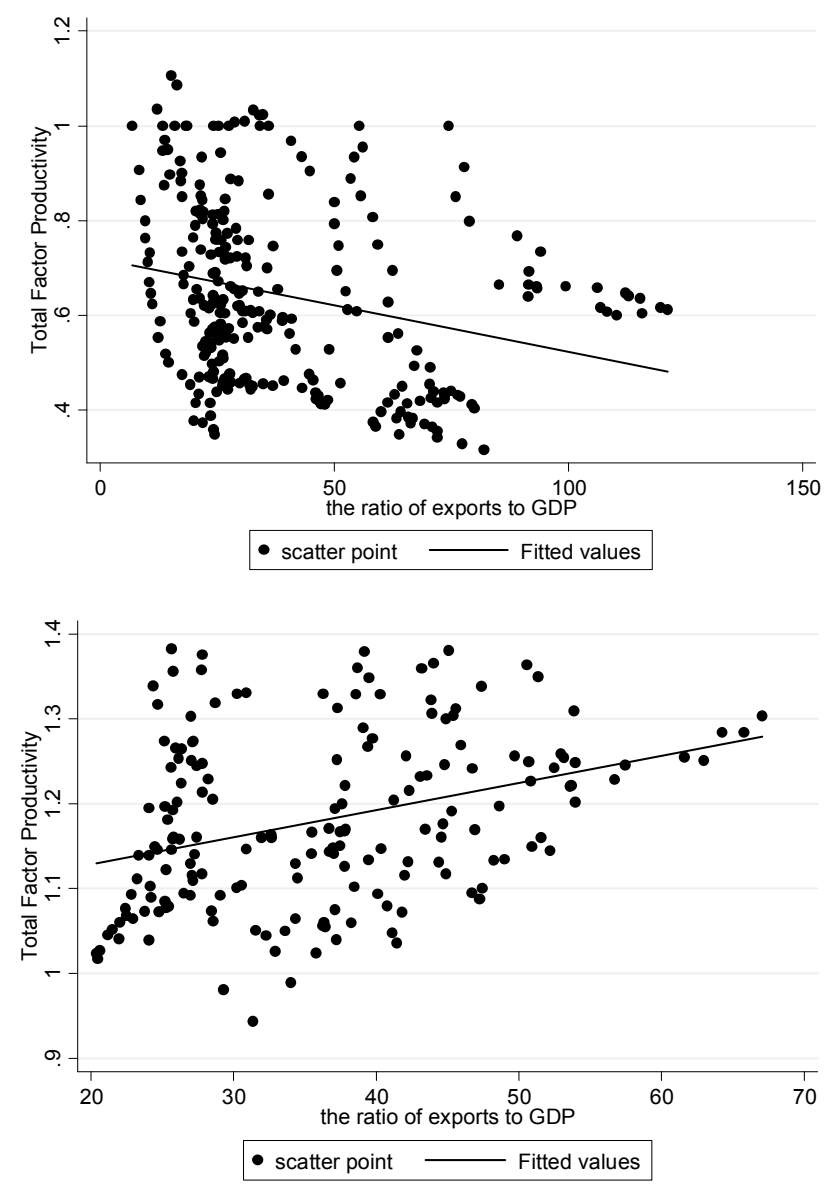

Fig. 1. The scatter diagram of exports and technology progress. 
Fig. 1 indicate that there exists a heterogeneity that the influence of exports on technology progress among different states. Based on this, we will conduct empirical study on "core" and "periphery" countries' panel data respectively. In order to avoid multicollinearity between exports and imports, we take exports growth rate as exports measurable indicator. Firstly, we use mixed ordinary least squares method to express the basic estimation results as the second column and the fifth column in table 4: Exports impede the technology progress in "periphery" countries, and the estimated results pass the $1 \%$ significance level, while exports prompt the technology progress in "core" countries. After endogenous test, the chi-square indicats that there exists endogenous problem within the data of "periphery" countries, and the heteroscedasticity D-W-H endogenous test also supports the existence of the endogeneity problem. We select export lagging behind a period as instrumental variable to conduct 2SLS regression. Shea's Partial R-Sq of the first stage regression almost equals to $1, \mathrm{~F}$ value is far greater than $1 \%$ significance level, so the instrumental variable is effective instrumental variable. The empirical results of 2SLS still steadily support the conclusion that exports hinder the technology progress in "periphery" countries. Taking into consideration that the panel data of different countries may have heteroscedasticity problem, we continue to conduct empirical study using GMM method. The results show that there is almost no difference between GMM and 2SLS. Although export lagging behind a period as the insturmental variable reaches $10 \%$ significance level, endogenous test shows that there is no endogenous problem within the data of "core" countries. Even under the condition of weak endogenous, the results of 2SLS and GMM empirical method still support the view that exports prompt the technology progress of "core" states. The detailed empirical results is the table as follows:

Table 4. Estimated result of heterogeneity among different countries.

\begin{tabular}{|c|c|c|c|c|c|c|}
\hline \multirow[b]{2}{*}{ Model } & \multicolumn{3}{|c|}{ "periphery" countries } & \multicolumn{3}{|c|}{ "core" countries } \\
\hline & OLS & 2SLS & GMM & OLS & 2SLS & GMM \\
\hline \multirow{2}{*}{$E x$} & $-0.009 * * *$ & $-0.009 * * *$ & $-0.009^{* * *}$ & $0.0215^{* * *}$ & $0.023 * * *$ & $0.023 * * *$ \\
\hline & $(-7.12)$ & $(-6.07)$ & $(-6.10)$ & (7.97) & $(7.96)$ & $(8.23)$ \\
\hline \multirow{2}{*}{$\operatorname{Im}$} & $0.00213 * * *$ & 0.0003 & 0.0003 & $0.00328^{*}$ & $0.003 *$ & 0.003 \\
\hline & (10.39) & $(0.37)$ & $(0.38)$ & $(1.95)$ & $(1.80)$ & (1.58) \\
\hline \multirow[b]{2}{*}{$F D I$} & $6.066^{* * *}$ & $4.331^{* * *}$ & $4.331^{* * *}$ & 0.479 & 0.514 & 0.514 \\
\hline & $(4.21)$ & $(2.79)$ & $(4.79)$ & $(0.70)$ & $(0.77)$ & $(1.15)$ \\
\hline \multirow[b]{2}{*}{$R \& D$} & $0.480^{* * * *}$ & $0.312^{* * *}$ & $0.312^{* * *}$ & $-0.105 * * *$ & $-0.116^{* * *}$ & $-0.116^{* * *}$ \\
\hline & $(2.73)$ & $(3.32)$ & (3.64) & $(-3.66)$ & $(-3.94)$ & $(-4.61)$ \\
\hline \multirow[b]{2}{*}{$C M$} & -0.001 & 0.000 & 0.000 & -0.00131 & $-0.001 * * *$ & $-0.001 * * *$ \\
\hline & $(-0.77)$ & $(0.31)$ & $(0.39)$ & $(-3.06)$ & $(-3.33)$ & $(-4.45)$ \\
\hline \multirow{2}{*}{ constant } & $-1.058^{* * *}$ & $-0.851^{* * *}$ & $-0.851^{* * *}$ & $1.318 * * *$ & $1.323 * * *$ & $1.323 * * *$ \\
\hline & $(-5.72)$ & $(-9.52)$ & $(-8.24)$ & $(21.35)$ & $(20.56)$ & $(23.34)$ \\
\hline Sargan-P Value & & 0.7292 & & & $10.26\left(^{*}\right)$ & \\
\hline \multirow{2}{*}{ Hausman endogenous test chi2 } & & \multirow{2}{*}{$44.38(* * *)$} & & \multirow{5}{*}{1.892} & 1.803 & \\
\hline & & & & & {$[0.18]$} & \\
\hline \multirow{2}{*}{ D-W-H endogenous test } & & 2.958 & & & & \\
\hline & & {$[0.087]$} & & & & \\
\hline Shea's Partial R-Sq & & 0.9592 & & & & \\
\hline
\end{tabular}

Note: the number of ( ) is the $\mathrm{t}$ statistical magnitude of regression coefficient, $* * *, * *, *$ indicate $1 \%, 5 \%$ and $10 \%$ significance level respectively.

Under the global production system dominated by multinational corporations of developed countries, the quantity and structure of "periphery" countries' export calculated based on the customs database converge to the standard of "core" countries gradually. But intra-production exports have coverd the unfair profit distribution among different value chain, meanwhile different value chain location also lead to heterogeneity that the influence of exports on technology progress. The "periphery" countries locate on the lower value chain of production and assembly part, so their exports cann't prompt technology progress. With the update speed of commodity accelerating and increasingly strict standard of intellectual property protection, The "periphery" countries face more difficult situation when these countries go forward to the upstream of the value chain.

\section{Conclusions and Inspiration}

This paper measure several major countries' total factor productivity including input of nature resources using DEA method, and then empirically test the influence of exports on technology progress base on the TFP data. Results show that: there exists large heterogeneity that the influence of exports on technology progress among difference countries on account of significant dummy variable of states. The empirical test of sub-samples indicates that exports prompt the technology progress in "core" countries, while exports hinder the technology progress in "periphery" countries.

One state's economic growth on long-run depends on institutional reform, the number of factor endowments and technology progress. Under the setting of Universal 
implementation of market economy in "periphery" countries, the influence of exports on institutional reform turns to be more faint. The influence of exports on "periphery" countries' economic growth on long-run mainly depends on the number of factor endowments and technology progress. According to the empirical results, exports hinder the technology progress in "periphery" countries. These countries always use the external market demand to stimulate economic growth, under the pressure of short-term economic growth. As to "periphery" countries, exports turn to be the fastest and most effective style to pull economic growth, which also form the path locking of low value-added goods exports. In order to support the long-run economic growth in "periphery" countries, the value created by exports should be supposed to retrieve the scarce resources and technology which are badly in need within domestic market. But under the international financial system dominated by the currency of "core" countries, developed countries dilute the foreign exchange reserves of "peripheral" countries through the fluctuation in exchange rate. Based on the analysis above, The exports of "peripheral" countries not only prompt the technology progress, but also output factor endowments indirectly, which go against the aim of long-run economic growth. Just as some southeast asian countries, the ratio of exports to GDP increase gradually, while the reality of economic growth is not optimistic. Review the exports of "core" countries: Firstly, in order to maintain the pisition of high-end value chain, relying on the domestic high levels of universities and scientific research institutes, headquarters of multinational companies in the developed countries throw all factors into technology research and development process which prompt their domestic technology progress. Secondly, The "core" countries realize to control the global production system through OFDI which output their high-end production factors, such as capital and technology. Thirdly, The value created by external high-end production factors will backflow to "core" countries through the opening international financial market, which can exchange primary products and raw materials with low added value from "peripheral" countries. Typical case is that "peripheral" countries using countless of shoes and shirts to exchange the Boeing aircrafts, the production process scattering at any place of the world which are organised by multinational firms in America. Although there exists large amount of trade deficit in U.S., the added value created by external production factors can support sustainable vast imports of low value-added goods. Judging from the market transaction, the exchange of commodity based on price is fair, but the amounts of factor endowments contained in equal value commodity are not equality. Nowadays, intra-production trade saves the consumption of factor endowments for "core" countries, and which is in favour of the long-run and sustainable development. The heterogeneity that influence of exports on technology progress between "core" countries and "peripheral" countries once again highlights the unfair transaction under the new stage of economic globalization. If things continue this way, the tendency of economic growth between "core" countries and "peripheral" countries will turn to be more divergent.

\section{References}

[1] Acemoglu, D., 2003, Patterns of Skills Premia, The Review of Economic Studies, Vol. 70, No 2, PP. 199-230.

[2] Alcala, F., Ciccone, A., 2004, Trade and Productivity, The Quarterly Journal of Economics, Vol. 119, No. 42, PP. 613-646.

[3] Bhagwati, J., 1996, The Miracle That Did Happen: Understanding East Asia in Comparative Perspective, Key Note Speech Delivered at Cornell University on the Occasion of Conference on Government and Market: The Relevance of the Taiwanese Performance to Development Theory and Policy in Honor of Professor Liu and Tsiang.

[4] Chow, G. C., 2007, China's Economic Transformation, Oxford: Blackwell.

[5] Delgado, M. A., Farinas, J. C., Ruano, S., 2002, Firm Productivity and Export Markets: A Non-Papametric Approach, Journal of International Economics, Vol. 57, No. 2, PP. $397-422$.

[6] Dilling-Hanse, M., Smith, V., 2015, R\&D, Export and Productivity in Business Services Firms: Testing the Bustos Model. Applied Economics Letters, Vol. 22, No. 16, PP. 1309-1314

[7] Felipe, J., 1997, Total Factor Productivity Growth in East Asia: A Critical Survey, Economics and Development Center Peport Series No. 65, Asian Development Bank, Manina.

[8] Goldsmith, R., 1951, A Perpetual Inventory of National Wealth, NBER Working Paper, No. 14.

[9] Grossman, G. M., Helpman, E., 1991, Trade, Knowledge Spillovers and Growth, European Economic Review, Vol. 35, No. 2, PP. 517-526.

[10] Hall, R. E., Jones, C. I., 1999, Why Do Some Countries Produce So Much More Output Per Worker Than Others?, The Quarterly Journal of Economics, Vol. 114, No.1, PP. 83-116.

[11] Krugman, P. R., 1979, Increasing Returns, Monopolistic Competition and International Trade, Journal of International Economics, Vol. 9, PP. 469-479.

[12] Krugman, P. R., 1994, The Myth of Asia's Miracle, Foreign Affairs, Vol. 73, No. 6, PP. 62-78.

[13] Long, V. N., Riezman, R., Soubeyran, A., 2007, Trade, Wage Gaps and Specific Human Capital Accumulation, Review of International Economics, Vol. 15, No. 1, PP. 75-92.

[14] Rodrigue, J., 2012, Multinational Production, Exports, and Aggregate Productivity, Review of Economic Dynamic, Vol. 17, PP. 243-261.

[15] Romer, P. M., 1986, Increasing Returns and Long-run Growth, Journal of Political Economy, Vol. 94, PP. 1002-1037.

[16] Stiglitz, J., 1974, Growth with exhaustible natural resources: Efficient and optimal growth paths, The Review of Economic Studies, Vol. 41, PP. 123-137.

[17] Thangavelu, S. M., Owyong, D. T., 2003, The Impact of Export Growth and Scale Economics on Productivity in Singapore's Manufacturing Industries, Journal of Economics Studies, Vol. 30, No. 6, PP. 623-635. 